\title{
A Comparative Phytochemical and Biological Study between Different Solvent Extracts of Bombax ceiba Roots Available in Bangladesh
}

\author{
Nazia Hoque*, Sabera Rahman, Ishrat Jahan, Meena Afroze Shanta, Nigar Sultana Tithi, \\ Nishat Nasrin
}

Department of Pharmacy, East West University, Dhaka, Bangladesh

Email: *nzh@ewubd.edu,naziabd03@yahoo.com

How to cite this paper: Hoque, N., Rahman, S., Jahan, I., Shanta, M.A., Tithi, N.S. and Nasrin, N. (2018) A Comparative Phytochemical and Biological Study between Different Solvent Extracts of Bombax ceiba Roots Available in Bangladesh. Pharmacology \& Pharmacy, 9, 53-66.

https://doi.org/10.4236/pp.2018.92005

Received: January 12, 2018

Accepted: February 25, 2018

Published: February 28, 2018

Copyright $\odot 2018$ by authors and Scientific Research Publishing Inc. This work is licensed under the Creative Commons Attribution International License (CC BY 4.0).

http://creativecommons.org/licenses/by/4.0/

c) (i) Open Access

\begin{abstract}
Use of different solvent systems for extraction of plant materials may cause variation in their bioactivities. The present study was conducted to evaluate the presence of different phytoconstituents and to compare in vitro bioactivities of petroleum ether, dichloromethane (DCM) and methanol extracts of Bombax ceiba (B. ceiba) roots available in Bangladesh. Preliminary phytochemical screening was conducted using specific standard procedure. Antioxidant activity of the extracts was evaluated using DPPH radical scavenging assay. Determination of total phenolic and flavonoid content was also carried out. Antibacterial and cytotoxic activities were investigated using disc diffusion method and brine shrimp lethality bioassay, respectively. All the experiments were carried out from February 2016 to September 2016. Phytochemical evaluation revealed the presence of alkaloids, terpenoids, carbohydrates, tannins, flavonoids, saponins and steroids. The methanol extract showed the highest DPPH radical scavenging activity and had the highest phenolic $(187.42 \pm 3.77 \mathrm{mg} / \mathrm{g}, \mathrm{GAE})$ and flavonoid content $(74.67 \pm 4 \mathrm{mg} / \mathrm{g}, \mathrm{QE})$ followed by the DCM and petroleum ether extracts. The extracts showed positive correlation between DPPH radical scavenging activity with the phenolic and flavonoid content. All the extracts showed mild to moderate in vitro antibacterial activity with zone of inhibition ranging from $7 \mathrm{~mm}$ to $13 \mathrm{~mm}$. In brine shrimp lethality bioassay, the observed $\mathrm{LC}_{50}$ values for petroleum ether, DCM and methanol extracts were $70.72 \mu \mathrm{g} / \mathrm{ml}, 37.72$ $\mu \mathrm{g} / \mathrm{ml}$ and $22.58 \mu \mathrm{g} / \mathrm{ml}$, respectively which revealed strong cytotoxic potential of the extracts compared to the positive control. The results indicated that $B$. ceiba roots could be a very potent source of natural radical scavenger and cytotoxic agent.
\end{abstract}




\section{Keywords}

Bombax ceiba, Antioxidant Activity, DPPH, Antibacterial Activity, Cytotoxic Effect

\section{Introduction}

Bombax ceiba (Local name: Silk Cotton tree, Family: Bombacaceae), is widely distributed in Bangladesh and also in temperate Asia, tropical Asia, western Africa and Australia [1]. For years, this plant has been used by the tribal populations of Asia. Stem barks of B. ceiba is used to cure gonorrhea, impotency, spermatorrhea, nocturnal emission and leucorrhoea by the people of Orissa, India. In Bangladesh, seeds and roots of $B$. ceiba have been used traditionally for the treatment of leprosy. Roots and barks of $B$. ceiba have been used to treat muscular injury by Chinese population [2]. Barks of $B$. ceiba have been found to lower blood glucose level, triglyceride level as well as cholesterol level in streptozotocin induced diabetic rats [3]. Studies also suggested that the stem, flowers and leaves of $B$. ceiba possess hepatoprotective, hypotensive, antioxidant properties as well as strong anti-inflammatory, antiviral, antibacterial and analgesic activities [4] [5]. It has been claimed in Ayurveda that the roots of $B$. ceiba are stimulant, astringent, restorative, demulcent, emetic and tonic [6].

Free radicals are crucial to any biochemical process and in case of aerobic life they play an important role in body's metabolism process. During respiration and some cell mediated immune functions, free radicals are continuously produced. Heart disease, cancer, diabetes, rheumatic disorder as well as aging are associated with excess level of free radicals [7]. Antioxidants, on the other hand, are the agents that react with the free radicals and neutralize their effects. Thus, antioxidants help to prevent many disorders that are associated with high level of oxidative stress. B. ceiba is one of the natural sources that have been reported to show antioxidant property [8].

It was found that reactive oxygen species (ROS) can change cell's normal gene transcription and signal transduction process followed by damage to DNA by modifying the base and altering DNA strands [9]. So it is very essential to find a natural agent which can be used safely as antioxidants as well as cytotoxic agents [10].

Multi-drug resistant microbial strains are increasing day by day and they show reduced susceptibility to antibiotics. The indiscriminate use of broad-spectrum antibiotics and immunosuppressive agents contribute to the multi-drug resistance and also various side effects [11]. Researchers are giving priority to identify new antimicrobial agents from nature. It has been observed that the secondary metabolites of higher plant origin may show novel mechanism of action along with their antimicrobial activity [12]. Besides, solvents with different polarity have pronounced effect on extracting bioactive molecules which cause variation in their bioactivities [13]. So, as a part of our ongoing investigation on local me- 
dicinal plants of Bangladesh and an attempt to evaluate the variation in pharmacological activities due to different solvent system [14] [15], we have reported here a study on the antioxidant, antimicrobial and cytotoxic activities of the different solvent extracts of $B$. ceiba roots.

\section{Materials and Methods}

\subsection{Chemicals and Solvents}

Chemicals and reagents were obtained from Sigma-Aldrich co. (USA), Merck (Germany) and Fine Chemicals (India). All the solvents used throughout the experiments were of analytical grades.

\subsection{Plant Collection and Extraction of the Plant Material}

The plant material was collected in February, 2016 from Rampura, Dhaka, Bangladesh and was identified and authenticated by Mr. Abdur Rahim, Technical Officer, Department of Botany, Jahangirnagar University. The roots were dried and pulverized into coarse powder. Two hundred grams of powdered plant materials were taken into sealed container and macerated for seven days at room temperature using 1.0 liter of petroleum ether with occasional shaking and stirring. Same procedure was repeated using dichloromethane (DCM) and methanol as solvents. The extracts were then filtered using sterilized cotton filter followed by whatman no 1 filter papers. The solvents were totally evaporated using rotary evaporator under reduced pressure at $40^{\circ} \mathrm{C}-50^{\circ} \mathrm{C}$ temperature. The obtained crude extracts were collected, weighed and then stored at $4^{\circ} \mathrm{C}$ until further use. Table 1 shows the yield percentages $(\mathrm{w} / \mathrm{w})$ of $B$. ceiba roots in different solvents used for extraction.

\subsection{Phytochemical Screening}

Chemical tests were carried out on the freshly prepared extracts using standard procedures to assess the existence of active phytochemical constituents. The following reagents and chemicals were used: alkaloids with Wagner's and Hager's reagent, carbohydrates with Molisch's test, tannins with $0.1 \%$ ferric chloride, terpenoids with modified Salkowski test, flavonoids with the use of concentrated hydrochloric acid, saponins with distilled water and glycosides by using alcohol with few drops of $\mathrm{H}_{2} \mathrm{SO}_{4}$, followed by neutralization with $\mathrm{NaOH}$ solution and boiling with Fehling's solution. These were identified by characteristic color changes using standard procedures [16].

Table 1. Yield \% of B. ceiba roots in different solvent extracts.

\begin{tabular}{cc}
\hline Solvent used & Yield \% \\
\hline Petroleum ether & 1.2 \\
Dichloromethane & 3.4 \\
Methanol & 3.8 \\
\hline
\end{tabular}




\subsection{Quantitative Phytochemical Analysis}

\subsubsection{Determination of Total Phenolic Content}

To determine the total phenolic content, $1 \mathrm{ml}$ of each extract $(250 \mu \mathrm{g} / \mathrm{ml})$ and the standard gallic acid $(50-250 \mu \mathrm{g} / \mathrm{ml})$ were oxidized with $10 \%$ Folin-Ciocalteu reagent and then neutralized with $700 \mathrm{mM}$ sodium carbonate solution. The obtained mixtures were allowed to stand for 60 minutes at room temperature and absorbance of the resulting solutions was taken at $765 \mathrm{~nm}$ against reagent blank [17]. A standard curve was prepared for gallic acid (Figure 1) and used to determine the total phenolic content of the extracts. The results were expressed as gallic acid equivalents (mg/g, GAE) and as mean $\pm \mathrm{SD}$.

\subsubsection{Determination of Total Flavonoid Content}

Aluminium chloride colorimetric method [18] was used to determine the flavonoid content. One milliliter of each extract $(250 \mu \mathrm{g} / \mathrm{ml})$ in methanol was mixed with $200 \mu \mathrm{l}$ of $10 \% \mathrm{w} / \mathrm{v}$ aluminium chloride and $1 \mathrm{M}$ potassium acetate solution. Then $5.6 \mathrm{ml}$ distilled water was added to the mixture and was kept at room temperature for 40 minutes. The absorbance of the resulting solutions was measured at $415 \mathrm{~nm}$ against reagent blank. Total flavonoid content of the extracts was determined from a standard curve prepared for quercetin (50 - $250 \mu \mathrm{g} / \mathrm{ml}$ ) solution (Figure 2). The estimated results were expressed as quercetin equivalents ( $\mathrm{mg} / \mathrm{g}, \mathrm{QE})$.

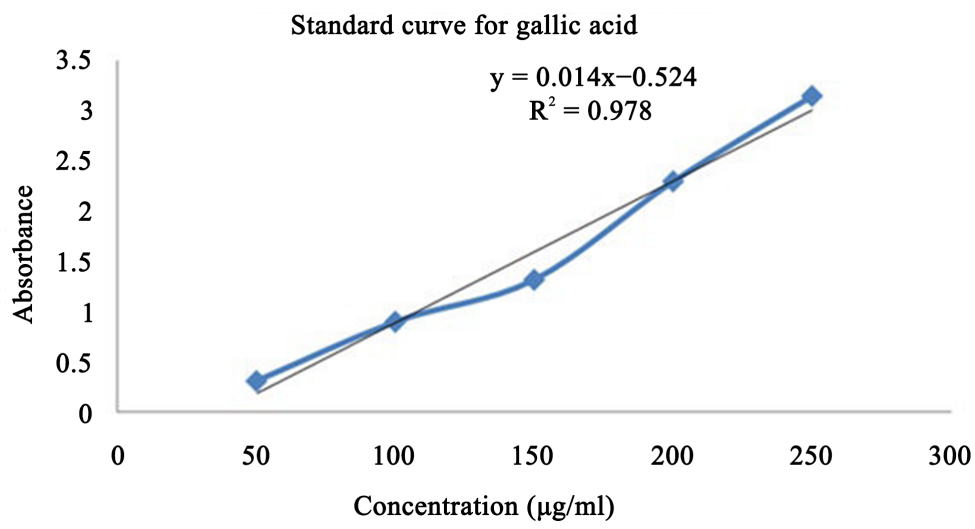

Figure 1. Standard curve for gallic acid.

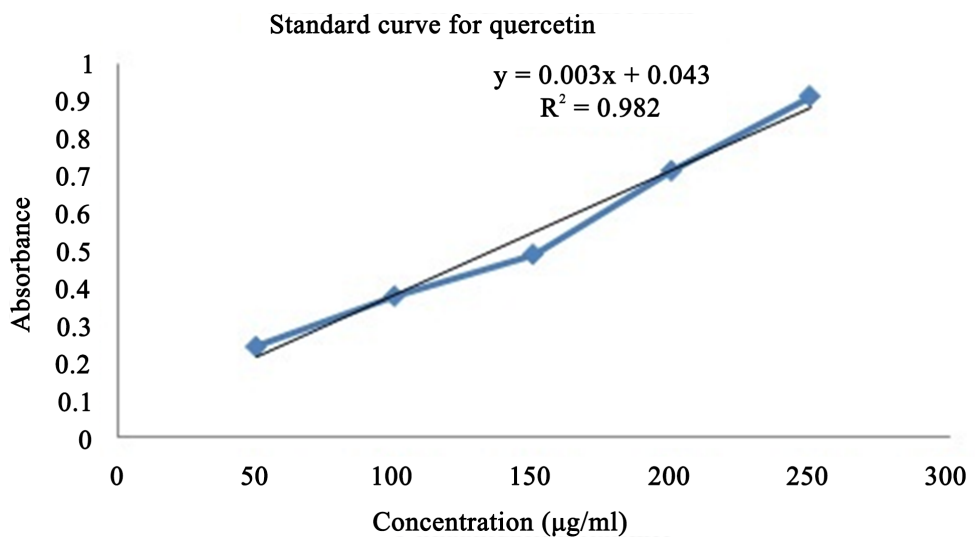

Figure 2. Standard curve for quercetin. 


\subsection{Antioxidant Activity}

\section{DPPH Radical Scavenging Activity}

Methanol was used to prepare a stock solution $(400 \mu \mathrm{g} / \mathrm{ml})$ of 2 ,

2-Diphenyl-1-picrylhydrazyl (DPPH) and $100 \mu \mathrm{l}$ of this stock solution was added to $5 \mathrm{ml}$ solution of the extracts and the standard (ascorbic acid) of different concentrations $(12.5-200 \mu \mathrm{g} / \mathrm{ml})$. After proper mixing the solutions were kept in dark for 20 minutes and by using a spectrophotometer (Shimadzu UV PC-1800), the absorbance of the solutions were measured at $517 \mathrm{~nm}$ against methanol. Scavenging activity was measured by reduction in the absorbance of methanol solution of DPPH and expressed as the percentage inhibition using the formula:

$$
\left[\left(A_{0}-A_{1}\right) / A_{0}\right] \times 100
$$

where $A_{0}$ is the absorbance of the control and $A_{1}$ is the absorbance of the extract/standard. $\mathrm{IC}_{50}$ values were calculated from the graph constructed as a plot of \% inhibition vs. concentration [19].

\subsection{Antibacterial Assay}

Five Gram-positive and six Gram-negative bacterial strains were used in the antibacterial assay following the disc diffusion method [20]. Suspension of each microorganism ( $100 \mu \mathrm{l}$, containing approximately 100 - $150 \mathrm{CFU} / \mathrm{ml})$ was spread over nutrient agar media and dried, sterile filter paper discs of $6 \mathrm{~mm}$ diameter were placed gently on those agar plates after impregnated with $300 \mu \mathrm{g}$ and 600 $\mu \mathrm{g}$ of different extracts prepared by dissolving them in methanol followed by evaporation. After 24 hours of incubation at $37^{\circ} \mathrm{C}$ the diameter of zone of inhibition was measured in mm. Kanamycin ( $30 \mu \mathrm{g} / \mathrm{disc})$ was used as positive control while blank disc (impregnated with solvents) was used as negative control.

\subsection{Cytotoxic Activity}

Cytotoxicity of different concentrations of each extract was identified using the brine shrimp lethality bioassay [21]. The eggs of brine shrimp (Artemia salina Leach) were hatched in a tank containing artificial sea water for 48 hours at a temperature around $37^{\circ} \mathrm{C}$ and $\mathrm{pH} 8.4$ with constant oxygen supply and allowed to be matured as nauplii. The extracts were dissolved in DMSO $(0.5 \% \mathrm{v} / \mathrm{v})$ and diluted to get final concentrations of $400,200,100,50,25,12.5,6.25,3.12$ and $1.56 \mu \mathrm{g} / \mathrm{ml}$. Seawater was added to the marked test tubes containing extracts to make final volume $5 \mathrm{ml}$ and 10 living nauplii were taken into each of the test tube. By keeping the total volume same, DMSO was taken as negative control and solutions of different concentrations of vincristine sulphate were taken as positive control. The number of surviving nauplii in the test tubes was counted after $24 \mathrm{~h}$ and the percentage of lethality was calculated for each concentration of the extracts and standard. 


\subsection{Statistical Analysis}

Statistical analyses were performed using Microsoft Excel, 2007. All experiments were repeated three times and results were expressed as mean values \pm SD.

\section{Results}

\subsection{Phytochemical Screening}

The phytochemical analysis of all extracts of $B$. ceiba roots revealed the presence of alkaloids, terpenoids, carbohydrates, tannins, flavonoids, saponins and steroids in varying amounts (Table 2 ).

\subsection{Quantitative Phytochemical Analysis}

\subsubsection{Total Phenolic Content}

Total phenolic content of the extracts was calculated using the standard curve plotted for gallic acid $\left(y=0.014 x-0.524 ; R^{2}=0.978\right)$ (Figure 1$)$. The methanol extract showed the highest amount of phenolic compounds $(187.42 \pm 3.77 \mathrm{mg} / \mathrm{g}$, GAE) followed by the DCM $(176.28 \pm 1.59 \mathrm{mg} / \mathrm{g}, \mathrm{GAE})$ and petroleum ether extracts $(162.47 \pm 4.52 \mathrm{mg} / \mathrm{g}, \mathrm{GAE})$ (Table 3$)$.

\subsubsection{Total Flavonoid Content}

Total flavonoid content of the extracts was calculated using the standard curve plotted for quercetin $\left(y=0.003 x+0.043 ; R^{2}=0.982\right)$ (Figure 2). The highest amount of flavonoid content was present in methanol extract $(74.67 \pm 4 \mathrm{mg} / \mathrm{g}$, QE) whereas the petroleum ether extract contained the lowest amount of flavonoid content (43.55 $\pm 2.77 \mathrm{mg} / \mathrm{g}$, QE) (Table 3).

Table 2. Results of chemical group tests of the extracts of B. ceiba roots.

\begin{tabular}{|c|c|c|c|c|c|c|c|}
\hline $\begin{array}{c}\text { Plant } \\
\text { extract }\end{array}$ & Alkaloids & Terpenoids & Carbohydrates & Tannins & Flavonoids & Saponins & Steroids \\
\hline $\begin{array}{l}\text { Petroleum } \\
\text { ether }\end{array}$ & + & + & + & + & + & + & + \\
\hline DCM & + & ++ & + & + & +++ & + & + \\
\hline Methanol & ++ & ++ & + & ++ & ++ & ++ & ++ \\
\hline \multicolumn{8}{|c|}{ +++: highly present, ++: moderately present, +: slightly present. DCM: Dichloromethane. } \\
\hline \multicolumn{8}{|c|}{$\begin{array}{l}\text { Table } 3 \text {. Total phenolic content and total flavonoid content of different extracts of } B \text {. } \\
\text { ceiba roots. }\end{array}$} \\
\hline \multicolumn{2}{|c|}{ Extracts } & \multicolumn{2}{|c|}{$\begin{array}{l}\text { Total phenolic content } \\
\quad \text { (in } \mathrm{mg} / \mathrm{g}, \mathrm{GAE} \text { ) }\end{array}$} & \multicolumn{4}{|c|}{$\begin{array}{l}\text { Total flavonoid content } \\
\text { (in } \mathrm{mg} / \mathrm{g}, \mathrm{QE} \text { ) }\end{array}$} \\
\hline \multicolumn{2}{|c|}{ Petroleum ether } & \multicolumn{2}{|c|}{$162.47 \pm 4.52$} & \multicolumn{4}{|c|}{$43.55 \pm 2.77$} \\
\hline \multicolumn{2}{|c|}{ DCM } & \multicolumn{2}{|c|}{$176.28 \pm 1.59$} & \multicolumn{4}{|c|}{$64.89 \pm 3.35$} \\
\hline \multicolumn{2}{|c|}{ Methanol } & \multicolumn{2}{|c|}{$187.42 \pm 3.77$} & \multicolumn{4}{|c|}{$74.67 \pm 4.0$} \\
\hline
\end{tabular}

Values are represented as mean \pm SD $(n=3)$. DCM: Dichloromethane. 


\subsection{Antioxidant Activity}

\subsubsection{DPPH Radical Scavenging Activity}

From the analysis of Figure 3, it can be concluded that the scavenging effect of the extracts was increased in a concentration dependent manner. The highest radical scavenging activity was shown by methanol extract $\left(\mathrm{IC}_{50}\right.$ : $144.77 \pm 3.61$ $\mu \mathrm{g} / \mathrm{ml}$ ) whereas petroleum ether extract showed the lowest activity $\left(\mathrm{IC}_{50}: 214.83\right.$ $\pm 5.37 \mu \mathrm{g} / \mathrm{ml}$ ). The $\mathrm{IC}_{50}$ values for the extracts and the standard (ascorbic acid) are given in Table 4.

\subsubsection{Correlation between Total Phenolic/Flavonoid Content with DPPH Scavenging Activity}

Correlation curves of DPPH scavenging assay with total phenol and flavonoid content had been developed (Figure 4(a) and Figure 4(b)). The Pearson's correlation coefficient $(r)$ and coefficient of determination $\left(R^{2}\right)\left(r=0.996, R^{2}=0.994\right)$ between total flavonoid content and DPPH scavenging activity was higher than those of total phenol content and DPPH scavenging activity $\left(r=0.974, \mathrm{R}^{2}=0.949\right)$.

\subsection{Antibacterial Assay}

When compared to the standard disc of kanamycin (30 $\mu \mathrm{g} / \mathrm{disc})$, the DCM extract showed mild to moderate antibacterial activities against all the strains except Salmonella typhi and the highest activity was observed against Sarcina lutea

\section{DPPH scavenging assay}

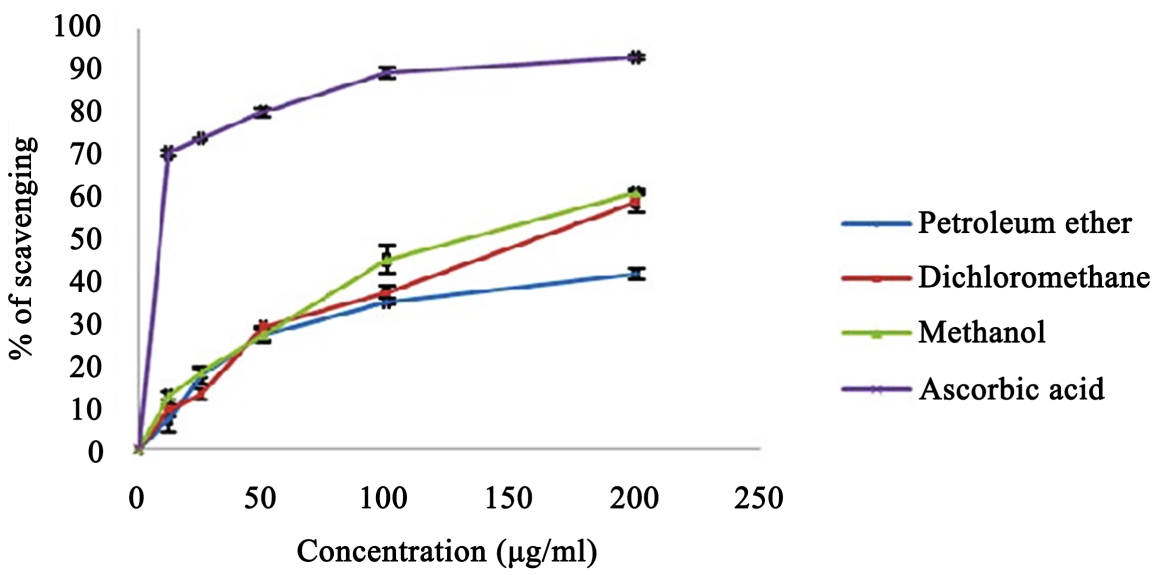

Figure 3. DPPH scavenging activity of different extracts of B. ceiba roots and ascorbic acid.

Table 4. $\mathrm{IC}_{50}$ values of different extracts of $B$. ceiba roots and ascorbic acid.

\begin{tabular}{cc}
\hline Extract/standard & IC $_{50}$ values $(\mu \mathrm{g} / \mathrm{ml})$ \\
\hline Petroleum ether & $214.83 \pm 5.37$ \\
DCM & $157.23 \pm 5.39$ \\
Methanol & $144.77 \pm 3.61$ \\
Ascorbic acid & $2.02 \pm 0.24$ \\
\hline
\end{tabular}

DCM: Dichloromethane. 


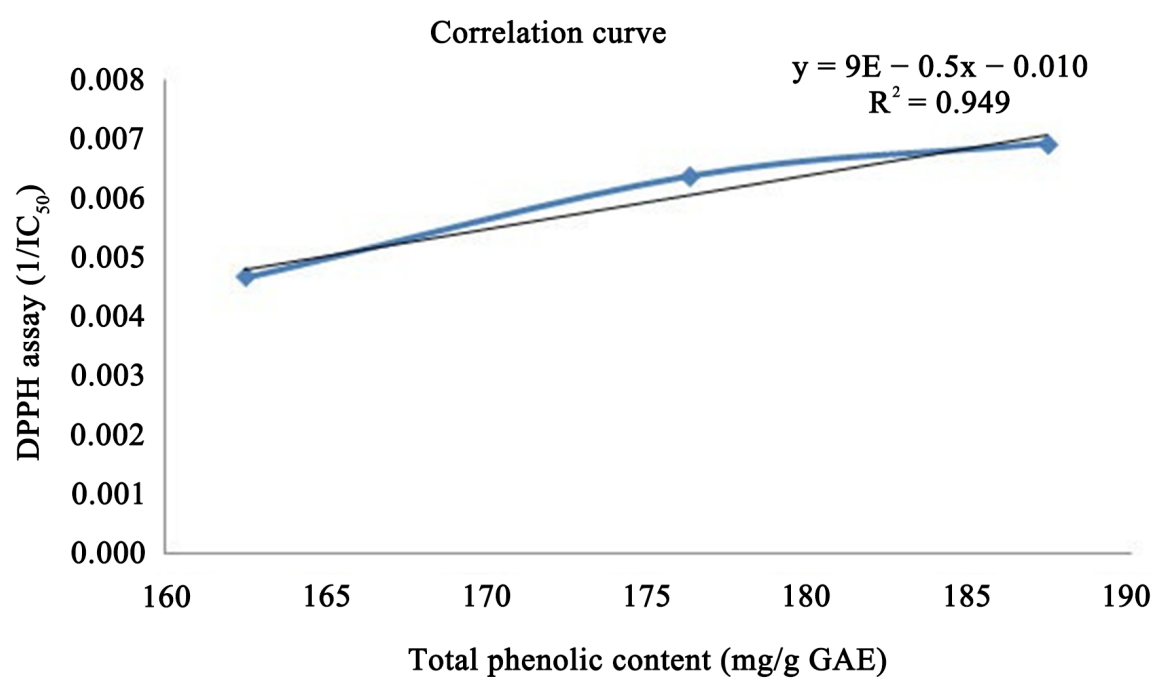

(a)

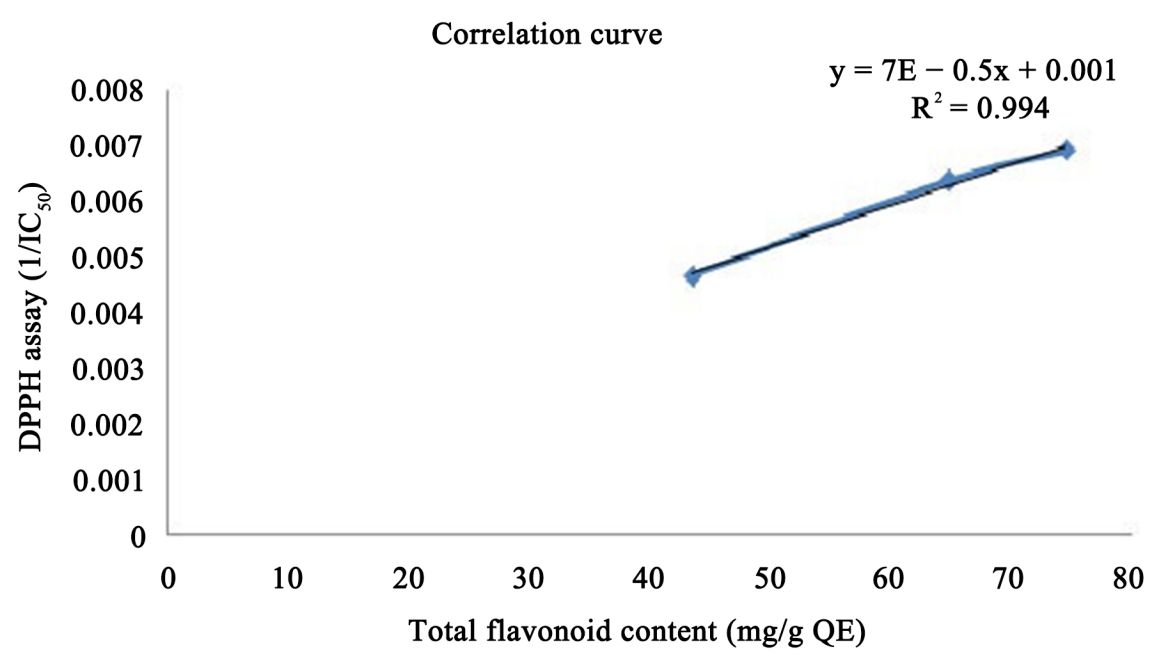

(b)

Figure 4. (a) Correlation curve between DPPH scavenging assay and total phenolic content; (b) Correlation curve between DPPH scavenging assay and total flavonoid content.

$(12.3 \pm 1.5 \mathrm{~mm}$ at $600 \mu \mathrm{g} / \mathrm{disc})$. The methanol extract displayed the highest zone of inhibition against Escherichia coli $(10.3 \pm 1.5 \mathrm{~mm}$ at $600 \mu \mathrm{g} / \mathrm{disc})$ although it did not show antibacterial activity against some of the strains. The petroleum ether extract was found active only against Staphylococcus aureus and Escherichia coli (Table 5).

\subsection{Cytotoxic Activity}

In brine shrimp lethality bioassay, the lowest $\mathrm{LC}_{50}$ value $(22.58 \mu \mathrm{g} / \mathrm{ml})$ was calculated for the methanol extract and the highest $\mathrm{LC}_{50}$ value $(70.72 \mu \mathrm{g} / \mathrm{ml})$ was estimated for the petroleum ether extract. The extracts showed strong cytotoxic activity compared to the standard vincristine sulphate $\left(\mathrm{LC}_{50}: 1.24 \mu \mathrm{g} / \mathrm{ml}\right)$ (Table 6 and Table 7). 
Table 5. Zone of inhibition of different extracts of B. ceiba roots and kanamycin.

\begin{tabular}{|c|c|c|c|c|c|c|c|}
\hline \multirow[b]{2}{*}{ Microorganisms } & \multicolumn{2}{|c|}{ Petroleum ether } & \multicolumn{2}{|c|}{$\mathrm{DCM}$} & \multicolumn{2}{|c|}{ Methanol } & \multirow{2}{*}{$\begin{array}{c}\text { Kanamycin } \\
30 \\
\mu \mathrm{g} / \mathrm{disc}\end{array}$} \\
\hline & $\begin{array}{c}300 \\
\mu \mathrm{g} / \mathrm{disc}\end{array}$ & $\begin{array}{c}600 \\
\mu \mathrm{g} / \mathrm{disc}\end{array}$ & $\begin{array}{c}300 \\
\mu \mathrm{g} / \text { disc }\end{array}$ & $\begin{array}{c}600 \\
\mu \mathrm{g} / \mathrm{disc}\end{array}$ & $\begin{array}{c}300 \\
\mu \mathrm{g} / \mathrm{disc}\end{array}$ & $\begin{array}{c}600 \\
\mu \mathrm{g} / \mathrm{disc}\end{array}$ & \\
\hline \multicolumn{8}{|c|}{ Gram-positive bacteria Zone of inhibition ( $\mathrm{mm}$ ) } \\
\hline Sarcina lutea & - & - & $8.3 \pm 0.5$ & $12.3 \pm 1.5$ & - & - & $30.1 \pm 0.1$ \\
\hline Bacillus megaterium & - & - & - & $7.3 \pm 0.5$ & - & $8.6 \pm 0.5$ & $30.0 \pm 0.5$ \\
\hline $\begin{array}{c}\text { Bacillus subtilis } \\
\text { ATCC } 6059\end{array}$ & - & - & $8.0 \pm 0.1$ & $11.0 \pm 0.1$ & - & - & $30.3 \pm 0.3$ \\
\hline $\begin{array}{c}\text { Staphylococcus } \\
\text { aureus ATCC } 25923\end{array}$ & - & $7.3 \pm 0.5$ & $7.3 \pm 0.5$ & $10.1 \pm 0.1$ & - & - & $34.0 \pm 0.5$ \\
\hline $\begin{array}{l}\text { Bacillus cereus } \\
\text { ATCC } 14579\end{array}$ & - & - & - & $8.3 \pm 0.5$ & - & $7.5 \pm 0.5$ & $30.0 \pm 0.5$ \\
\hline \multicolumn{8}{|c|}{ Gram-negative bacteria } \\
\hline $\begin{array}{c}\text { Pseudomonas } \\
\text { aeruginosa } \\
\text { ATCC } 27853\end{array}$ & - & - & $8.4 \pm 0.1$ & $11.0 \pm 1.0$ & & $7.3 \pm 0.5$ & $28.1 \pm 0.1$ \\
\hline $\begin{array}{l}\text { Salmonella typhi } \\
\text { ATCC } 13311\end{array}$ & - & - & - & - & - & $7.3 \pm 0.5$ & $17.5 \pm 0.6$ \\
\hline $\begin{array}{l}\text { Escherichia coli } \\
\text { ATCC } 25922\end{array}$ & - & $7.3 \pm 0.5$ & $8.0 \pm 1.0$ & $12.0 \pm 0.5$ & $8.1 \pm 0.1$ & $10.3 \pm 1.5$ & $30.3 \pm 0.3$ \\
\hline $\begin{array}{l}\text { Vibrio mimicus } \\
\text { ATCC } 33653\end{array}$ & - & - & - & $8.0 \pm 0.5$ & - & - & $13.5 \pm 0.6$ \\
\hline $\begin{array}{l}\text { Shigella boydii } \\
\text { ATCC } 13147\end{array}$ & - & - & - & $8.2 \pm 0.2$ & - & - & $23.0 \pm 0.5$ \\
\hline $\begin{array}{c}\text { Shigella dysenteriae } \\
\text { ATCC } 26131\end{array}$ & - & - & $8.5 \pm 0.6$ & $9.6 \pm 0.6$ & $7.5 \pm 0.5$ & $9.3 \pm 1.5$ & $24.2 \pm 0.2$ \\
\hline
\end{tabular}

Values are expressed as mean $\pm \mathrm{SD} ; \mathrm{n}=3$. '-' indicates no zone of inhibition. DCM: Dichloromethane.

Table 6. \% mortality of brine shrimp larvae at different concentrations of extracts and vincristine sulphate.

\begin{tabular}{cccccc}
\hline \multirow{2}{*}{$\begin{array}{c}\text { Concentration } \\
(\mu \mathrm{g} / \mathrm{ml})\end{array}$} & Log $\mathrm{C}$ & $\begin{array}{c}\text { Petroleum } \\
\text { ether }\end{array}$ & DCM & Methanol & $\begin{array}{c}\text { Vincristine } \\
\text { sulphate }\end{array}$ \\
\hline 400 & 2.60206 & 90 & 100 & 100 & 100 \\
200 & 2.30103 & 70 & 80 & 100 & 100 \\
100 & 2 & 50 & 70 & 80 & 100 \\
50 & 1.69897 & 40 & 50 & 70 & 100 \\
25 & 1.39794 & 30 & 30 & 40 & 100 \\
12.5 & 1.09691 & 10 & 20 & 30 & 90 \\
6.25 & 0.79588 & 10 & 10 & 10 & 90 \\
3.125 & 0.49485 & 10 & 10 & 10 & 70 \\
1.5625 & 0.19382 & 0 & 0 & 0 & 50 \\
\hline
\end{tabular}

$\%$ mortality of brine shrimp larvae after 24 h. DCM: Dichloromethane. 
Table 7. Cytotoxic activity of various extracts of $B$. ceiba roots and vincristine sulphate.

\begin{tabular}{cc}
\hline Extracts & LC $_{50}$ values $(\mu \mathrm{g} / \mathrm{ml})$ \\
\hline Petroleum ether & 70.72 \\
DCM & 37.72 \\
Methanol & 22.58 \\
Vincristine sulphate & 1.24 \\
\hline
\end{tabular}

DCM: Dichloromethane.

\section{Discussion}

The medicinal value of plants links to presence of bioactive phytochemicals that display definite physiological action on human which can be used in treating many diseases. Previous studies on different medicinal plants showed that the existence of secondary metabolites are correlated with the therapeutic properties such as antioxidant, antimicrobial, anti-inflammatory, antidiabetic etc. [22]. In this study, phytochemical tests demonstrated the presence of alkaloids, terpenoids, carbohydrates, tannins, flavonoids, saponins and steroids in all extracts in varying amounts.

$\mathrm{DPPH}$ radical scavenging activity can be used to measure the electron donating ability and free radical scavenging ability of natural products [23]. In present days, use of natural antioxidants get higher acceptances over synthetic antioxidants because of various toxic effects of the later on human body [24]. In this study, petroleum ether, DCM and methanol extracts of $B$. ceiba roots exhibited moderate to strong concentration dependent $\mathrm{DPPH}$ radical scavenging activity compared to the standard (ascorbic acid) which also showed consistent results with the previous studies done by others [5] [25].

Determination of phenolic compounds in plant extract has proven to be significantly important as polyphenolic compounds in plants can act as free radical scavengers or antioxidants. The aromatic (benzene) rings of the polyphenols are substituted by hydroxyl groups or other functional derivatives. These groups have the capability to absorb free radicals and reactive oxygen species (ROS) which may lead to several pathological conditions including cancer [26] [27]. Among the polyphenols, flavonoids also prevent body from various diseases as their molecular structure and position of hydroxyl groups make them potent antioxidants [28]. Besides different types of chemical compounds are dissolved in solvents with different polarity, such as high amount of phenolic compounds are dissolved in polar solvents [29]. Our study exhibited similar results where the methanol extract of $B$. ceiba roots showed the highest amount of phenol and flavonoid content compared to petroleum ether and DCM extracts. Moreover, correlation curves of DPPH scavenging assay with total phenol and flavonoid content had been developed. Literature reports have suggested that there is a correlation between the total phenolic content and antioxidant activity of plant extracts [30]. The high correlations show that the presence of phenol and flavonoid compounds in the extracts may contribute to their antioxidant activity. 
DCM and methanol extracts exhibited mild to moderate antibacterial activity against certain Gram-positive and Gram-negative bacteria whereas petroleum ether exhibited very low activity only against $S$. aureus and $E$. coli. Among the three extracts, DCM extract exhibited antibacterial activity against all the Gram-positive and Gram-negative bacteria except $S$. typhi examined at the concentration of $600 \mu \mathrm{g} / \mathrm{disc}$. The antibacterial activity exerted by the extracts may be due to the likely presence of alkaloids, steroids and tannins [31] [32] [33], although this needs to be confirmed by further research.

Petroleum ether, DCM and methanol extracts of B. ceiba roots showed concentration dependent increment in percent mortality of brine shrimp nauplii. In this study, methanol extract showed the highest cytotoxic activity $\left(\mathrm{LC}_{50}: 22.58\right.$ $\mu \mathrm{g} / \mathrm{ml}$ ) compared to DCM and petroleum ether extracts. All the extracts showed strong cytotoxic activities compared to the standard vincristine sulphate. Phytochemical screening indicated the likely presence of terpenoids which are reported to have bactericidal, fungicidal, antiviral, cytotoxic, analgesic, anti-inflammatory, anticancer and antiallergic activity [34]. Thus, the observed cytotoxic activity may be attributed to the presence of terpenoids; however, this needs to be confirmed. The potential cytotoxic activity exhibited by the extracts used in this study is also supported by other works that demonstrated strong cytotoxic activity of B. ceiba [35] [36].

The results obtained from the study showed that different extracts of $B$. ceiba roots possess potential antioxidant, antibacterial and cytotoxic properties which demonstrate clearly the scientific basis of traditional uses of the plant. So, the present study suggests that $B$. ceiba roots can be a useful source to lead the development of new drugs. Further studies are required to establish its antioxidant activity by other in vitro and in vivo methods, cytotoxic activity against different cancer cell lines and to identify the chemical compounds responsible for such activities.

\section{Acknowledgements}

The authors are grateful to the Department of Pharmacy, East West University, Dhaka, Bangladesh for providing proper facilities to conduct the research.

\section{Conflict of Interest Statement}

We declare that we have no conflict of interest.

\section{References}

[1] Vartica, J. and Verma, S.K. (2014) Assessment of Credibility of Some Folk Medicinal Claims on Bombax ceiba L. Indian Journal of Traditional Knowledge, 13, 87-94.

[2] Chaudhary, P.H. and Khadabadi, S.S. (2012) Bombax ceiba Linn.: Pharmacognosy, Ethnobotany and Phyto-Pharmacology. Pharmacognosy Communications, 2, 2-9. https://doi.org/10.5530/pc.2012.3.2

[3] Bhavsar, C.J. and Talele, G.S. (2013) Potential Anti-Diabetic Activity of Bombax ceiba. A Journal of the Bangladesh Pharmacological Society, 8, 102-106. 
https://doi.org/10.3329/bjp.v8i2.13701

[4] Ravi, V., Patel, S.S., Verma, N.K., Dutta, D. and Saleem, T.S.M. (2010) Hepatoprotective Activity of Bombax ceiba Linn against Isoniazid and Rifampicin-Induced Toxicity in Experimental Rats. International Journal of Applied Research in Natural Products, 3, 19-26.

[5] Jain, V., Verma, S.K., Katewa, S.S., Anandjiwala, S. and Singh, B. (2011) Free Radical Scavenging Property of Bombax ceiba Linn. Root. Research Journal of Medicinal Plant, 5, 462-470. https://doi.org/10.3923/rjmp.2011.462.470

[6] Chaudhary, P.H., Rai, P.D., Deore, S.L. and Khadabadi, S.S. (2014) Pharmacognostical and Phytochemical Studies on Roots of Bombax ceiba Linn. Journal of Pharmacy and Pharmacognosy Research, 2, 172-182.

[7] Tiwari, A.K. (2001) Imbalance in Anti-Oxidant Defence and Human Diseases: Multiple Approach of Natural Anti-Oxidants Therapy. Current Science, 81, 1179-1187.

[8] Nuttall, S.L., Kendall, M.J. and Martin, U. (1999) Antioxidant Therapy for the Prevention of Cardiovascular Disease. Q J Med: An International Journal of Medicine, 92, 239-244. https://doi.org/10.1093/qjmed/92.5.239

[9] Collins, A. (1999) Oxidative DNA Damage, Antioxidants and Cancer. Bioessays, 21, 238-246. https://doi.org/10.1002/(SICI)1521-1878(199903)21:3<238::AID-BIES8>3.0.CO;2-3

[10] Tundis, R., Rashed, K., Said, A., Menichini, F. and Loizzo, M.R. (2014) In vitro Cancer Cell Growth Inhibition and Antioxidant Activity of Bombax ceiba (Bombacaceae) Flower Extracts. Natural Product Communications, 9, 691-694.

[11] Dabur, R., Gupta, A., Mandal, T.K., Singh, D.D., Bajpai, V., Gurav, A.M., et al. (2007) Antimicrobial Activity of Some Indian Medicinal Plants. African Journal of Traditional, Complementary and Alternative Medicine, 4, 313-318. https://doi.org/10.4314/ajtcam.v4i3.31225

[12] Divya, N., Nagamani, J.E. and Prabhu, S. (2012) Antioxidant and Antihemolytic Activities of Bombax ceiba Pentandra Spike and Fruit Extracts. International Journal of Pharmacy and Pharmaceutical Science, 4, 311-315.

[13] Vuong, Q.V., Hiruna, S., Roacha, P.D., Bowyera, M.C., Phillips, P.A. and Scarlett, C.J. (2013) Effect of Extraction Conditions on Total Phenolic Compounds and Antioxidant Activities of Carica papaya Leaf Aqueous Extracts. Journal of Herbal Medicine, 3, 104-111. https://doi.org/10.1016/j.hermed.2013.04.004

[14] Hoque, N., Faysal, A.A., Ahmed, I., Akanda, M.R.Z. and Chowdhury, N.S. (2015) In vitro Antioxidant, Antimicrobial and Cytotoxic Activities of the Various Extracts of Ganoderma lucidum Available in Bangladesh. Journal of Pharmacognosy and Phytochemistry, 4, 42-46.

[15] Hoque, N., Sohrab, M.H., Debnath, T. and Rana, M.S. (2016) Antioxidant, Antibacterial and Cytotoxic Activities of Various Extracts of Thysanolaena maxima (Roxb) Kuntze Available in Chittagong Hill Tracts of Bangladesh. International Journal Pharmacy and Pharmaceutical Science, 8, 168-172.

[16] Ghani, A. (2003) Medicinal Plants of Bangladesh with Chemical Constituents and Uses. 2nd Edition, Asiatic Society of Bangladesh, Dhaka.

[17] Ainsworth, E.A. and Gillespie, K.M. (2007) Estimation of Total Phenolic Content and Other Oxidation Substrates in Plant Tissue Using Follin-Ciocalteu Reagent. Nature Protocols, 2, 875-877. https://doi.org/10.1038/nprot.2007.102

[18] Kumaran, A. and Karunakaran, A.J. (2007) In vitro Antioxidant Activities of Methanol Extracts of Five Phyllanthus Species from India. LWT-Food Science and Technology, 40, 344-352. https://doi.org/10.1016/j.lwt.2005.09.011 
[19] Apu, A.S., Liza, M.S., Jamaluddin, A., Howlader, M.A., Saha, R.K. and Rizwan, F. (2012) Phytochemical Screening and in vitro Bioactivities of the Extracts of the Aerial Part of Boerhavia diffusa Linn. Asian Pacific Journal of Tropical Biomedicine, 2, 673-678. https://doi.org/10.1016/S2221-1691(12)60208-1

[20] Bauer, A.W., Kirby, W.M.M., Sherries, J.C. and Turck, M. (1966) Antibiotic Susceptibility Testing by a Standardized Single Disc Method. American Journal of Clinical Pathology, 45, 493-496. https://doi.org/10.1093/ajcp/45.4_ts.493

[21] Meyer, B., Ferringni, N., Putnam, J., Jacobsen, L., Nichols, D. and McLaughlin, J. (1982) Brine Shrimp: A Convenient General Bioassay for Active Plant Constituents. Planta Medica, 45, 31-34. https://doi.org/10.1055/s-2007-971236

[22] Yadav, M., Chatterji, S., Gupta, S.K. and Watal, G. (2014) Preliminary Phytochemical Screening of Six Medicinal Plants Used in Traditional Medicine. International Journal of Pharmacy and Pharmaceutical Science, 6, 539-542.

[23] Umamaheswari, M. and Chatterjee, T.K. (2008) In vitro Antioxidant Activities of the Fractions of Coccinia grandis L. Leaf Extract. African Journal of Traditional, Complementary and Alternative Medicine, 5, 61-73.

https://doi.org/10.4314/ajtcam.v5i1.31258

[24] Jayaprakash, G.K. and Rao, L.J. (2000) Phenolic Constituents from Lichen Parmontrema Stuppeum. (Nyl.) Hale and Their Antioxidant Activity. Zeitschrift für Naturforschung, 55, 1018-1022.

[25] Rani, S., Rahman, K. and Sultana, A. (2016) Ethnomedicinal and Pharmacological Activities of Mochrus (Bombax ceiba Linn.): An Overview. Tang [Humanitas Medicine], 6, 1-9. https://doi.org/10.5667/tang.2015.0025

[26] Liao, K. and Yin, M. (2000) Individual and Combined Antioxidant Effects of Seven Phenolic Agents in Human Erythrocyte Membrane Ghosts and Phosphatidylcholine Liposome System: The Importance of the Partition Coefficient. Journal of Agricultural and Food Chemistry, 48, 2266-2270. https://doi.org/10.1021/jf990946w

[27] Iqbal, E., Salim, K.A. and Lim, L.B.L. (2015) Phytochemical Screening, Total Phenolics and Antioxidant Activities of Bark and Leaf Extracts of Goniothalamus velutinus (Airy Shaw) from Brunei Darussalam. Journal of King Saud University-Science, 27, 224-232. https://doi.org/10.1016/j.jksus.2015.02.003

[28] Rajanandh, M.G. and Kavitha, J. (2010) Quantitative Estimation of $\beta$-Sitosterol, Total Phenolic and Flavonoid Compounds in the Leaves of Moringa oleifera. International Journal of Pharm Tech Research, 2, 1409-1414.

[29] Canadanovic-Brunet, J., Cetkovic, G., Dilas, S., Tumbas, V., Bogdanovic, G., Mandic, A, et al. (2008) Radical Scavenging, Antibacterial and Antiproliferative Activities of Melissa officinalis L. Extracts. Journal of Medicinal Food, 11, 133-143. https://doi.org/10.1089/jmf.2007.580

[30] Zhang, Y. and Wang, Z. (2009) Phenolic Composition and Antioxidant Activities of Two Phlomis Species: A Correlation Study. Comptes Rendus Biologies, 332, 816-826. https://doi.org/10.1016/j.crvi.2009.05.006

[31] Alexei, Y.B., Joseph, I.S. and Olga, V.F. (2009) Endogenous Cardiotonic Steroids: Physiology, Pharmacology and Novel Therapeutic Targets. Pharmacological Review, 61, 9-38. https://doi.org/10.1124/pr.108.000711

[32] Akiyama, H., Fujii, K., Yamasaki, O., Oono, T. and Iwatsuki, K. (2001) Antibacterial Action of Several Tannins against Staphylococcus aureus. Journal of Antimicrobial Chemotherapy, 48, 487-491. https://doi.org/10.1093/jac/48.4.487

[33] Benbott, A., Yahyia, A. and Belaidi, A. (2012) Assessment of the Antibacterial Activity of Crude Alkaloids Extracted from Seeds and Roots of the Plant Peganum 
harmala L. Journal of Natural Product and Plant Resource, 2, 568-573.

[34] Narayana, K.R., Reddy, M.S., Chaluvadi, M.R. and Krishna, D.R. (2001) Bioflavonoids Classification, Pharmacological, Biochemical Effects and Therapeutic Potential. Indian Journal of Pharmacology, 33, 2-16.

[35] Srikanth, M., Rao, B.G. and Rao, T.M. (2013) Anticancer Activity of Various Extracts of Musa rosacea, Avicennia marina and Bombax ceiba. International Journal of Pharmacy and Pharmaceutical Science, 5, 553-555.

[36] Islam, M.K., Chowdhury, J.A. and Eti, I.Z. (2011) Biological Activity Study on a Malvaceae Plant: Bombax ceiba. Journal of Scientific Research, 3, 445-450.

https://doi.org/10.3329/jsr.v3i2.5162 